\title{
A practical method to design the solar photovoltaic system applied on residential building in Indonesia
}

\author{
Prisma Megantoro ${ }^{1}$, Pinto Anugrah ${ }^{2}$, Yusrizal Afif ${ }^{3}$, Lilik Jamilatul Awalin ${ }^{4}$, P. Vigneshwaran ${ }^{5}$ \\ ${ }_{1,3,4}$ Faculty of Advanced Technology and Multidisicipline, Universitas Airlangga, Indonesia \\ ${ }^{2}$ Department of Electrical Engineering, Faculty of Engineering, Universitas Andalas, Indonesia \\ ${ }^{5}$ Department of CSE, SRM Institute of Science \& Technology, Kattankulathur, Chennai, India
}

\begin{tabular}{l} 
Article Info \\
\hline Article history: \\
Received May 19, 2021 \\
Revised Jul 29, 2021 \\
Accepted Aug 8, 2021 \\
\hline Keywords: \\
Electricity consumption \\
Photovoltaic \\
Reliable electricity \\
Renewable energy \\
Solar home system
\end{tabular}

\begin{abstract}
The use of solar PV system in Indonesia has expanded to various field and area. One example is residential buildings in urban areas. This article discusses calculation methods for designing a solar power generation system that is applied to residential buildings, such as homes, offices, or colleges. Electricity generated from the solar home system (SHS) is used to support many kinds of electrical equipments, where the electrical equipments are used by building occupants in their daily life. The calculation method is considered from the potential of solar energy and the reliability of the on-site system to generate electricity. The system is designed in an off-grid topology by exchanging connections with the public electricity grid owned by PLN. Calculation results shows that this SHS has a generation capacity of $1 \mathrm{kWp}$, $24 \mathrm{~V} 300$ Ah battery storage, and a $200 \mathrm{~W}$ inverter. This SHS can reduce electricity usage in this sector by $18.2 \mathrm{kWh}$ in average every month.
\end{abstract}

This is an open access article under the CC BY-SA license.

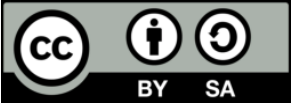

\section{Corresponding Author:}

Prisma Megantoro

Faculty of Advanced Technology and Multidiscipline

Universitas Airlangga

Surabaya, Indonesia

Email: prisma.megantoro@stmm.unair.ac.id

\section{INTRODUCTION}

The solar power generation system has been applied to a variety of purposes and locations that require electricity supply apart from the public electricity grid. In Indonesia, many solar power plants use photovoltaic technology. This technology uses silicon wafers to convert sunlight energy into electrical energy [1]-[4]. The use of solar power generation systems has been very diverse, such as centralized generators, distributed generators, solar home systems [5]-[7], solar water pumping systems [8]-[10], public street lighting [11]-[15] and also in the operation of electric vehicles [16]. Many of these systems have also been utilized to reduce the consumption of electrical energy from public networks with a smart-grid topology. This system topology is commonly used in residential sectors [17]-[22]. This topology allows the solar power generation system to be integrated with the public electricity network to increase the availability of electricity for users [23]-[25]. The demand to build a solar home system (SHS) in residential sector in Indonesia is also increasing, related to the government's policy to buy and sell electricity with the state electricity company (PLN). Apart from being a source of backup electricity, this system is also useful for reducing electricity bills for the public grid. In designing this system, the correct calculation method is always needed so that the solar power generation system that is built can operate optimally [26]-[29]. The calculations carried out must also consider various parameters of the installation site conditions and the specifications of each component of the solar power generation system. 
Several studies related to calculation methods for systems that utilize sunlight energy sources to meet electricity needs have been carried out. One of them is the research conducted by the author to design a solar water pumping system for the residential sector [9]. A study was also conducted by Diantari and Pujotomo. in designing a solar power system with a capacity of $5 \mathrm{~kW}$ [30]. Khin et al. estimated solar radiation and optimal tilt angle in photovoltaic systems in campus buildings [31]. A research that designed software to calculate the potential for solar radiation and based on the location coordinates that have been conducted by Bukvina et al. [32].

The research in this article proposes a method for calculating the SHS requirement for electrical loads in the residential sector. The calculation will involve the parameters of the potential solar irradiation at the site and the electricity load per day. Calculations are carried out sequentially from the electricity load per day, the estimated solar irradiation rate per day, to the number and specifications of each SHS component. This article will also discuss the results of the implementation of the SHS design that was built on the rooftop of the Nanizar Zaman Joenoes Building at Airlangga University Campus C, which is located in Surabaya, Indonesia.

\section{RESEARCH METHOD}

The method in this research is used to determine the total electrical energy required by a residential building every day, and to consider what are the type of electric load and how long it is used in a day. The solar energy potential at the location is expressed in terms of solar irradiation levels and peak sun hours (PSH). These two variables are used to calculate the type, number, and specifications of each SHS component that will be installed on-site. This is so that the designed system can meet the electricity needs of residential buildings. Only in this study, the electric load which is the target for meeting the energy supply covers the entire electrical load in the building, but only for a part of the lighting. The SHS design is shown in the block diagram Figure 1.

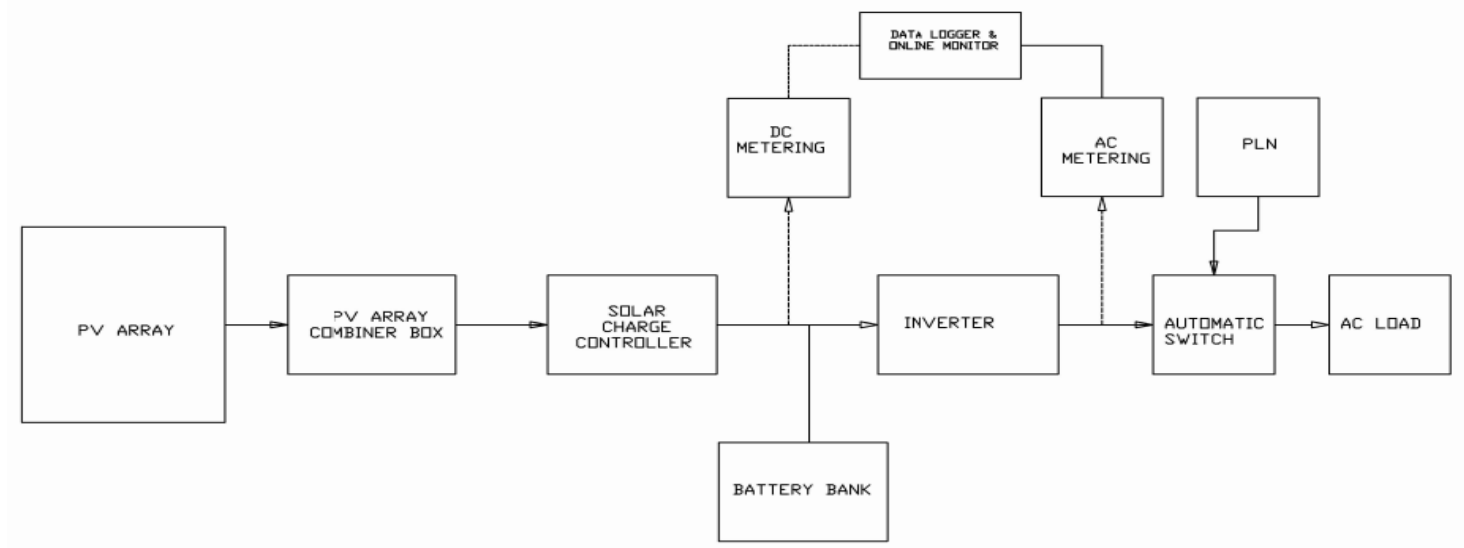

(a)

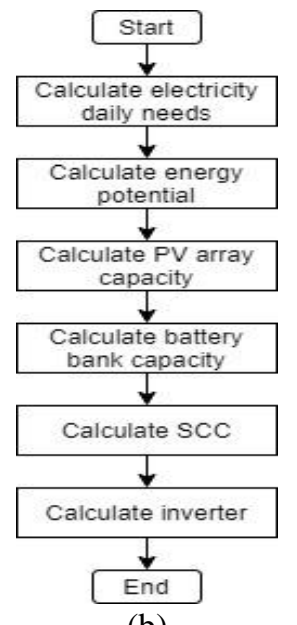

(b)

Figure 1. (a) SHS block diagram, (b) SHS system calculation flow chart 
Figure 1 (a) shows the general components of a solar power generation system, including the SHS. The system consists of an array of photovoltaic (PV) panels and a solar charge controller (SCC) as the generation unit. Array battery as a storage unit. Inverters as distribution units for electrical loads. Also, a metering unit in the form of a datalogger or control panel is needed to monitor system performance. The calculation method showed in Figure 1 (b) is used to determine the capacity and specification of each part of SHS. The consideration of SHS design is based on daily loads and energy potential in the area, so the method needs to calculate them first. Then, the capacity of PV array need to be calculated by the consideration of the 2 parameters mentioned before. The calculation of battery bank capacity is needed for the next process because it used to store the energy from PV array. Afterwards, is the calculation of SCC and inverter that used as electrical energy conversion.

\subsection{Electricity daily needs calculation}

The total demand for electrical energy used in some buildings in a day can be calculated by the (1).

$$
E_{\text {total }}=\sum n x t
$$

where $E_{\text {total }}$ is the sum of total electrical energy needs for each electricity device per day, $n$ is the number of each electricity device that has been used per day, $t$ is the time for each device is used per day.

\subsection{Solar energy potential calculation}

Surabaya is located at coordinate $07^{\circ} 09^{\prime} 00^{\prime \prime}-07^{\circ} 21^{\prime} 00^{\prime \prime}$ South Latitude and $112^{\circ} 36^{\prime}-112^{\circ} 54^{\prime}$ East Longitude. If this method will applied to other locations, then just change the global horizontal insolation (GHI) value for the coordinates of the location obtained from RETScreen. GHI of the location is obtained from the RETScreen climate data accessed at 23 March 2021 showed in Table 1. According to [33], average daylight hours (ADH) in Indonesia is 12 hours a day. Then direct normal insolation (DNI) could calculated in average per month with (2).

$$
D N I=\frac{G H I}{A D H}
$$

Table 1 . Secondary data of daily averaged insolation incident on a horizontal surface

\begin{tabular}{ccc}
\multicolumn{3}{c}{ (source: RETScreen database for Surabaya region) } \\
\hline Month & GHI $\left(\mathrm{kWh} / \mathrm{m}^{2} /\right.$ day $)$ & DNI $\left(\mathrm{kW} / \mathrm{m}^{2}\right)$ \\
\hline January & 4.57 & 0.38 \\
February & 4.90 & 0.41 \\
March & 4.91 & 0.41 \\
April & 4.93 & 0.41 \\
May & 4.77 & 0.39 \\
June & 4.76 & 0.39 \\
July & 4.69 & 0.38 \\
August & 4.86 & 0.40 \\
September & 5.04 & 0.42 \\
October & 4.89 & 0.40 \\
November & 4.66 & 0.38 \\
December & 4.47 & 0.37 \\
Average & 4.79 & 0.40 \\
\hline
\end{tabular}

The value of insolation used to calculate the need of solar panels is the average value by the minimum for each month, i.e,

$$
P_{\text {minimum_DNI }}=0.37 \mathrm{kWh} / \mathrm{m}^{2}
$$

By retrieving the value of the minimum DNI, we expected that SHS system can work optimally even in the condition at rainy season. The analysis of the energy needs is provided by solar panels which are obtained from the amount of energy consumed by the load per day.

The DNI value can be used to reference the output power that a solar panel can produce in the array when it is installed on-site. For example, if the solar panel on the datasheet has an output power capacity of $100 \mathrm{Wp}$, it means that the solar panel can produce the same power value only when getting $1000 \mathrm{~W} / \mathrm{m}^{2}$ dunlight insulation and a temperature $32{ }^{\circ} \mathrm{C}$. The light and temperature insulation parameters are obtained in the standard test condition (STC). So if the solar panel is installed at a location that has a DNI of 0.37 $\mathrm{kW} / \mathrm{m}^{2}$, it will have a maximum output power of $37 \mathrm{~W}$. 


\subsection{PV panel array capacity}

The first thing that will be calculated from the SHS design is the number and capacity of the PV panels. PV panels are a major component in the generation unit of a solar power plant. This component converts solar radiation energy into electrical energy. This calculation will involve one more parameter known as peak sun hours (PSH). is a parameter to express the ratio of the maximum duration of solar irradiation (in hours) per day to the standard solar radiation intensity which is $1 \mathrm{~kW} / \mathrm{m}^{2}$, the unit of PSH is the hour. According to [34], the PSH value in Indonesia is 4-5 hours per day. In this study we take the PSH value is 5 hours. With the total consumption of electrical energy that has been calculated, the required total capacity of the PV panel $P_{p v}$ array can be calculated in the (4).

$$
P_{\text {pv_com }}=\frac{E_{\text {total }}}{\text { PSH } x P_{\text {minimum_DNI }}}
$$

With the PV panel capacity expressed in $P_{p v_{-} c o m}$, it is possible to design a series and parallel connection configuration for a solar panel array. It is used as a reference for determining the operating voltage and current in the generation unit. The SHS design also considers the electrical losses that occur in each component of the system. This is described in Table 2.

From Table 2 it is known that the total losses of the solar PV system are 6.5\%. Electrical properties refer to the properties of silicon wafers (solar cells) which are required to create a voltage difference in cells when exposed to sunlight. Several components can cause a voltage drop, including resistors. The cable itself has a small amount of internal resistance, the amount of which will be based on the size (thickness) of the wire and its length. Connection losses capture resistive losses across the cable and diode connectors. The NREL study found a loss value of $0.5 \%$ for this component. The efficiency of a solar PV module also depends on one of its characteristic, namely the external quantum efficiency (EQE). EQE is the ratio between a number of charge carrier collected by solar cells with the number of incident photons [33]. EQE includes the effect of optical losses such as transmission and reflection. However, it is often useful to look at the quantum efficiency of the light left after the reflected and transmitted light has been lost. Ananda determined the measurement method to calculate the EQE for a PV module [34]. It is intended to capture events that completely paralyze the system - including inverter shutdown or failure, grid outage, or other actions that disconnect the PV system and prevent it from generating electricity for the home. Standard silicon solar panels consist of a silicon wafer, a connecting busbar, an encapsulating material, a glass and polymer backing sheet, and other electrical connection components. Over time, these components will wear and tear due to the effects of thermal expansion and contraction, UV rays, and damage from windblown particles, causing the system to degrade.

Table 2. Total losses of a PV system

\begin{tabular}{ccc}
\hline Losses & Percent of Losses (\%) & Efficiency (\%) \\
\hline Multi crystalline PV module & 0.5 & 99.5 \\
Wiring & 2 & 98 \\
Connection & 0.5 & 99.5 \\
System Availability & 3 & 97 \\
System Degradation & 0.5 & 99.5 \\
Total losses (Loss & \\
Total) & 6.5 & \\
source: https://www.aurorasolar.com/blog/understanding-pv-system-losses-part-1/)
\end{tabular}

$$
P_{p v_{-} \text {total }}=\frac{P_{p v_{-} \text {com }}}{\left(100 \%-\text { Loss }_{\text {Total }} \%\right)}
$$

The PV panel array configuration is expressed in terms of the number of parallel and serial connections. Parallel connection $\left(n_{p}\right)$ will double current, while series connection $\left(n_{s}\right)$ will double the voltage.

$$
n_{s_{-} p v}=\frac{V_{\text {system }}}{V_{m p}}
$$

where $V_{\text {system }}$ is operational voltage of the SHS and $V_{m p}$ is PV voltage at maximum power.

$$
n_{p_{-} p v}=\frac{P_{p v_{-} t o t a l}}{P_{p v}}
$$

where $P_{p v}$ is maximum power output of each PV panel. 


\subsection{Battery capacity}

This SHS will be activated to meet the electricity needs for 24 hours, therefore a storage system is needed. This storage system is useful so that SHS can generate electricity for 24 hours. The storage system uses a battery array to store the electrical energy generated by the generation unit. The storage system capacity considers the total energy that the generation unit produces during PSH. This is because, during $\mathrm{PSH}$, the generation unit produces the maximum output power according to STC.

$$
W_{\text {battery }}=P_{\text {pv_com }} \times \text { PSH }
$$

where $W_{\text {battery }}$ is the capacity of the storage system expressed in energy (Wh $/ \mathrm{kWh}$ ). Where this energy is the product of the battery voltage $\left(V_{\text {battery }}\right)$ which is expressed in units of Volts times the current capacity of the battery. Solar power generation systems are indeed suitable for using VRLA type batteries either dry or gel with a deep discharge (DoD) of $80 \%$. This type of battery that has DoD is a deep cycle type. If the operating voltage of the system is $24 \mathrm{~V}$, the current capacity that must be provided by the battery array $\left(I_{\text {bat_total }}\right)$ is calculated from the (9).

$$
I_{\text {bat_total }}=\frac{W_{\text {battery }}}{V_{\text {system }} \times D o D}
$$

This system uses a battery configured in series and parallel. The number of batteries arranged in series using the (10).

$$
n_{s_{-} b a t}=\frac{V_{\text {system }}}{V_{\text {bat }}}
$$

where $V_{\text {bat }}$ is each battery's voltage rate in specification sheet.

$$
n_{p_{-} \text {bat }}=\frac{W_{\text {battery }}}{V_{\text {system }} \times I_{\text {bat }}}
$$

where $I_{b a t}$ is each battery's current rate in specification sheet stated in Ah.

As with PV panel arrays, the parallel connection will double the current capacity, while the series connection will double the voltage.

\subsection{SCC specification}

SCC functions to optimize the process of producing electrical energy from the PV panel array. In general, SCC has a maximum power point tracking (MPPT) feature. Where this feature serves to track the maximum power point voltage of the PV panel array. The DC/DC converter in the SCC will change the charging voltage of the electric current to that voltage. This will increase the production of electrical energy and increase the efficiency of the system. This MPPT feature usually uses certain programming algorithms to perform its function, such as genetic algorithms [35]-[38]. Calculation of the capacity and specifications of the SCC takes into account the system voltage and specifications of the PV panel used. The calculation of voltage and current specification must fulfilled.

$$
V_{s c c}=n_{p} x V_{o c}
$$

Where; $V_{s c c}$ is SCC's voltage, $n_{p}$ is number of PV panel connected in parallel, and $V_{o c}$ is PV panel's open circuit voltage.

$$
I_{s c c}=I_{s c} \times n_{s} \times 1.5
$$

where; $I_{s c c}$ is SCC's current capacity needed and $n_{s}$ is number of PV panel connected in series. Then, they are must multiplied by 1.5 as $50 \%$ compensation to create safety configuration. The $50 \%$ compensation is needed to prevent overcurrent come from PV array.

\subsection{Inverter specification}

The inverter device functions to convert DC electricity to AC. This device is needed because almost all electrical equipment uses AC power. In general, determining the inverter capacity in a solar power plant only considers the total power used by all loads plus compensation of $25 \%$. This is considered to avoid overloading or "in-rush" current generated by inductive electric loads. The inverter capacity is calculated by the (14). 


$$
P_{\text {inverter }}=\left(\sum V_{\text {load }} \times I_{\text {load }}\right) \times 1.25
$$

where $V_{\text {load }}$ is voltage of every electricity load has been used and $I_{\text {load }}$ is RMS current of every electricity loaf has been used.

\subsection{Data analyze for SHS installed}

Analysis of data from the SHS that has been built on the rooftop of the Nanizar Zaman Joenoes Building, Campus C, Airlangga University. The SHS design uses the calculation method as described in the previous section. This data analysis is used to determine the success of the SHS design for the institutional residential sector in meeting the needs of several electrical equipments and reducing the consumption of electrical energy from the public power grid. Data analysis is carried out taking into account the input and output parameters of the SHS, as well as knowing the characteristics of the system model from upstream to downstream.

\section{IMPLEMENTATION}

The implementation of the SHS design calculation method is applied to the construction of an SHS with a capacity of $1 \mathrm{kWp}$. This SHS is used to supply a number of lighting points in the building. The SHS connection to the public electricity network is utilizing an automatic switch (ATS). The electricity generated by the SHS is fully used for lighting points for 24 hours.

If this SHS is used to turn on 15 lamps with a power of $10 \mathrm{~W}$, and they are turned on for 12 hours per day, then the total power that must be fulfilled is $1800 \mathrm{Wh}$ per day. Calculated by (4), the value of $P_{p v_{-} \text {com }}$ is $972 \mathrm{Wp}$. If the value of losses is entered into the (9), the total required PV panel array capacity is $1040 \mathrm{Wp}$, rounded up to $1 \mathrm{kWp}$. According to the standard, a solar power plant that has a capacity of more than or equal to $1 \mathrm{kWp}$ must have an $24 \mathrm{~V}$ operational voltage $\left(V_{\text {system }}\right)$. Therefore, the PV panel array is configured into 2 series to meet the operating voltage requirements.

The calculation of the number and specifications of the battery is considered from the electrical energy that can be stored. Then based on a (8), the electrical energy that must be stored by the battery array $\left(W_{\text {battery }}\right)$ is $5200 \mathrm{Wh}$, then the $I_{\text {bat_total }}$ value on this SHS is $270 \mathrm{Ah}$, rounded up to $300 \mathrm{Ah}$.

The calculation of the SCC specification is considered from the specifications, configuration, and the number of PV panels used. Based on (6), with the $V_{o c}$ on the PV panel is $21.1 \mathrm{~V}$, a minimum voltage specification of $42.2 \mathrm{~V}$ is required. ased on (7), with the $I_{s c}$ value on the PV panel of $4.32 \mathrm{~A}$, a minimum current specification of $43.2 \mathrm{~A}$ is required. The SCC used must have a power of $P_{s c c}$.

$$
P_{s c c}=42.2 \mathrm{~V} \times 43.2 \mathrm{~A}=1823 \mathrm{~W}
$$

The calculation of the inverter specification uses a reference for the amount and amount of RMS power for each load used. In the research, the electric load was 15 units of lighting lamps with an RMS power of $10 \mathrm{~W}$ each, so the inverter power that must be fulfilled plus $25 \%$ compensation is $P_{\text {inverter }}$.

$$
P_{\text {inverter }}=15 \times 10 \mathrm{~W} \times 125 \%=187 \mathrm{~W}
$$

\section{RESULTS AND ANALYSIS \\ 4.1. SHS design}

The results of the implementation of the calculation of each SHS component are contained in this section along with the detailed engineering design for each configuration design of SHS units. Based on Figure 2, if the design use a PV panel with a P_pv of $50 \mathrm{Wp}$, based on (6) and (7), it will need 2 series 10 parallel configurations. The required number of PV panels is 20 units. The cable used in the PV panel array uses the NYYHY type with a size of $4 \times 4 \mathrm{~mm}$ square. The choice of this cable type is appropriate for use in outdoor areas and is more resistant to air and weather. The cable size is of course adjusted to the current. 


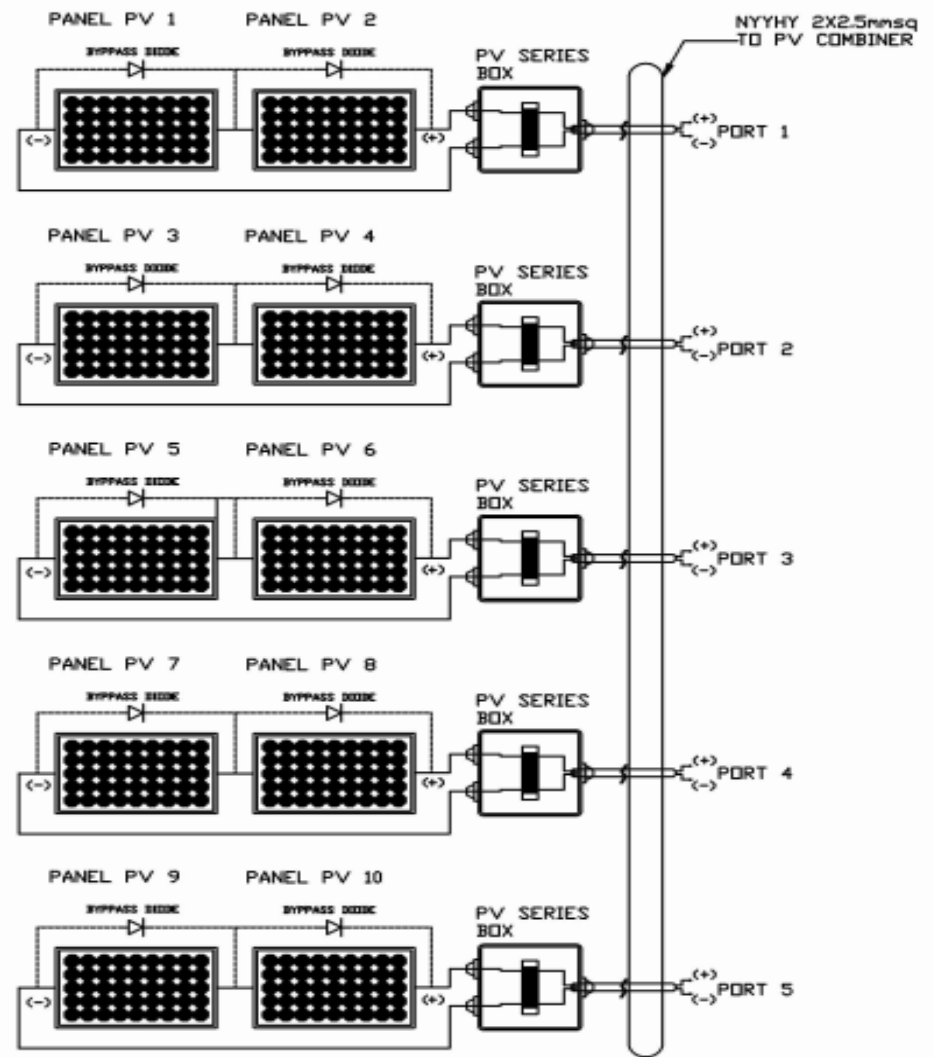

(a)

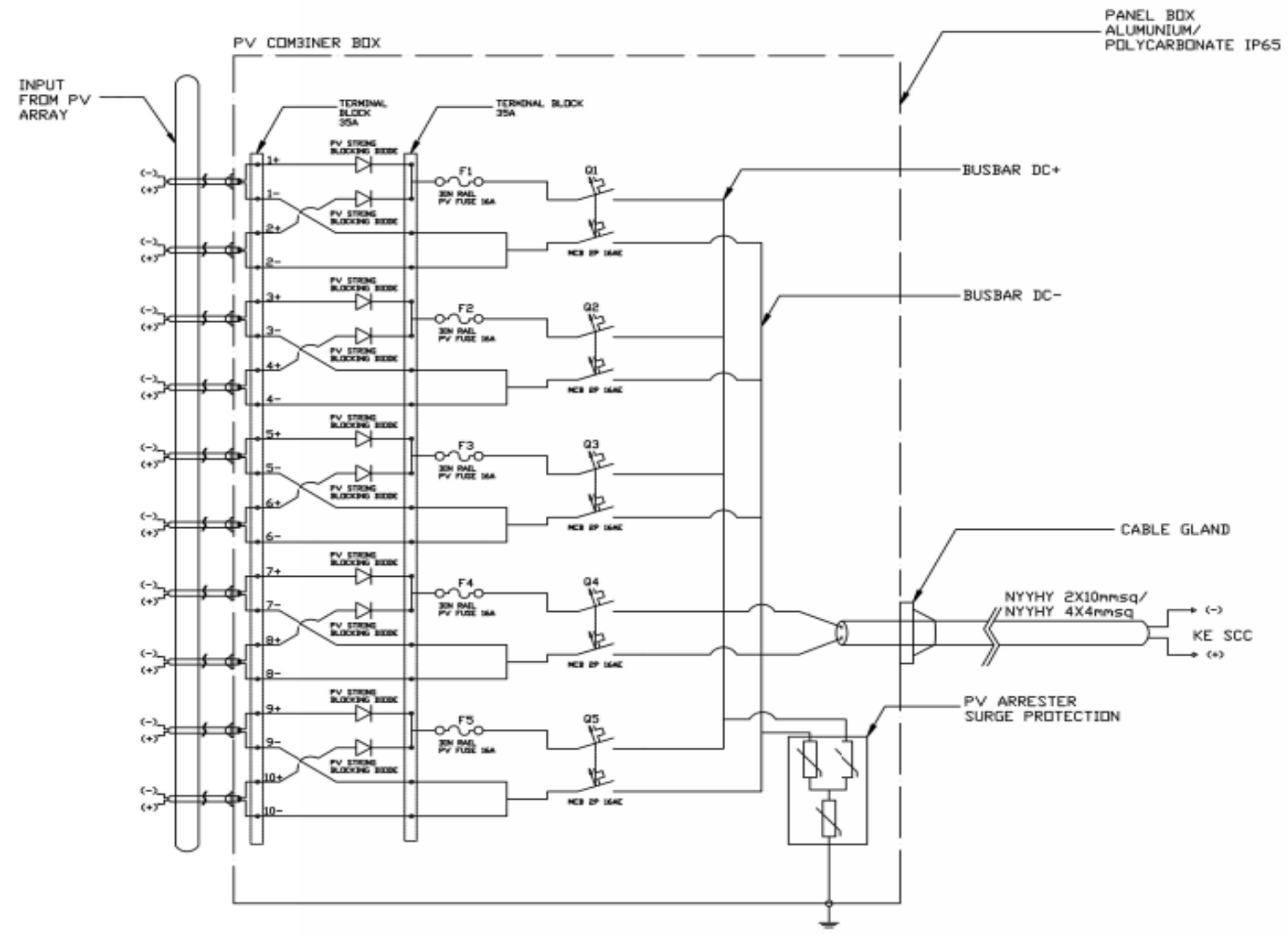

(b)

Figure 2. Configuration of array PV panel; (a) PV connection in first array, (b) all PV panel wiring diagram 
Based on Figure 3, if the design use a deep cycle battery with a voltage specification of $12 \mathrm{~V}$ and 50 Ah. According to (9) and (10), 6 units are needed with a configuration of 2 series and 3 parallels. Figure 4 shows the SHS design with a single line diagram that places all the designed SHS components to be reliable with design inputs. Along with wiring specifications and configuration of all system components. Coupled with a datalogger and metering from the DC and AC sides, as well as an exhaust fan on the battery panel. The wiring in the controller panel on the DC side uses the NYAF type with a size of $10 \mathrm{~mm}$ square. Wiring on the AC side uses NYH type with $2.5 \mathrm{~mm}$ square. The type of cable showed in Figure 4 is following the standard of use. Meanwhile, the size is adjusted to the voltage and electric current.

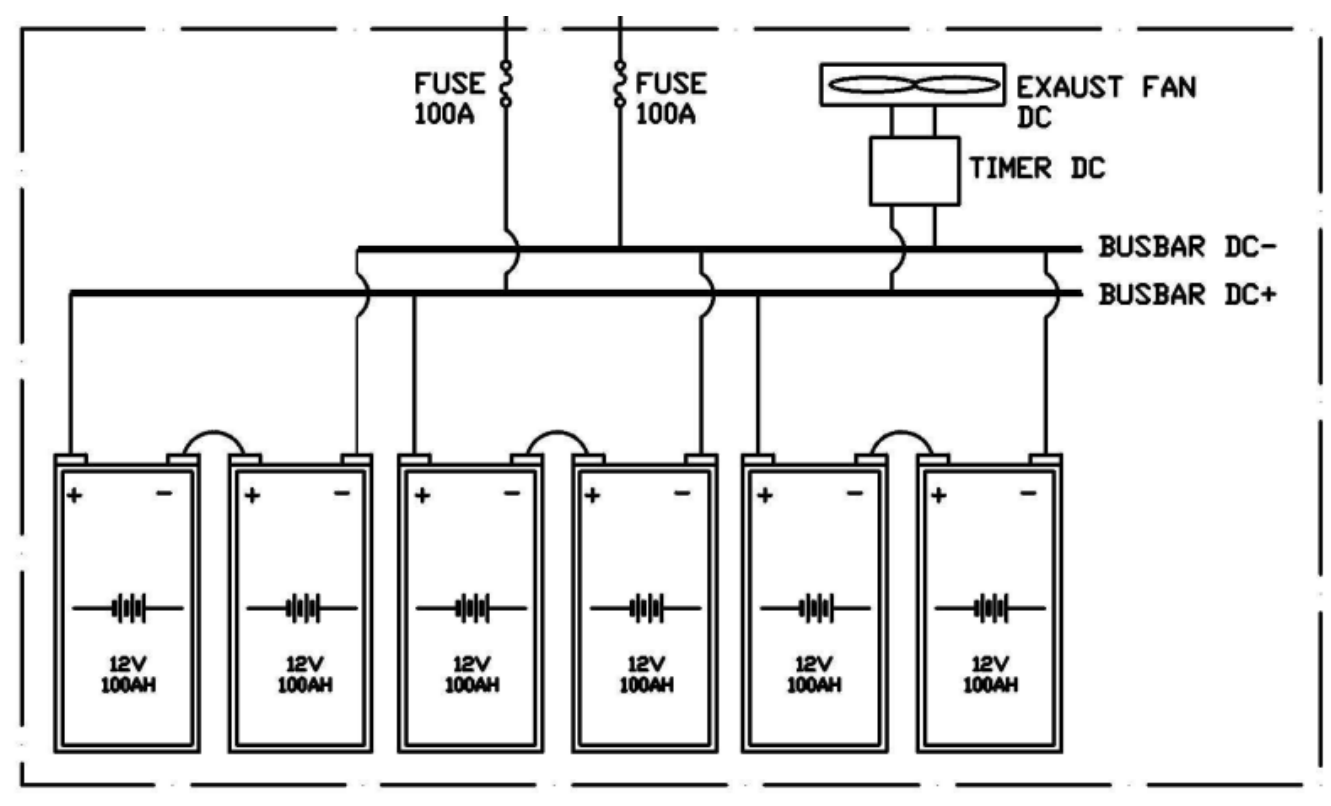

Figure 3. Configuration of battery array

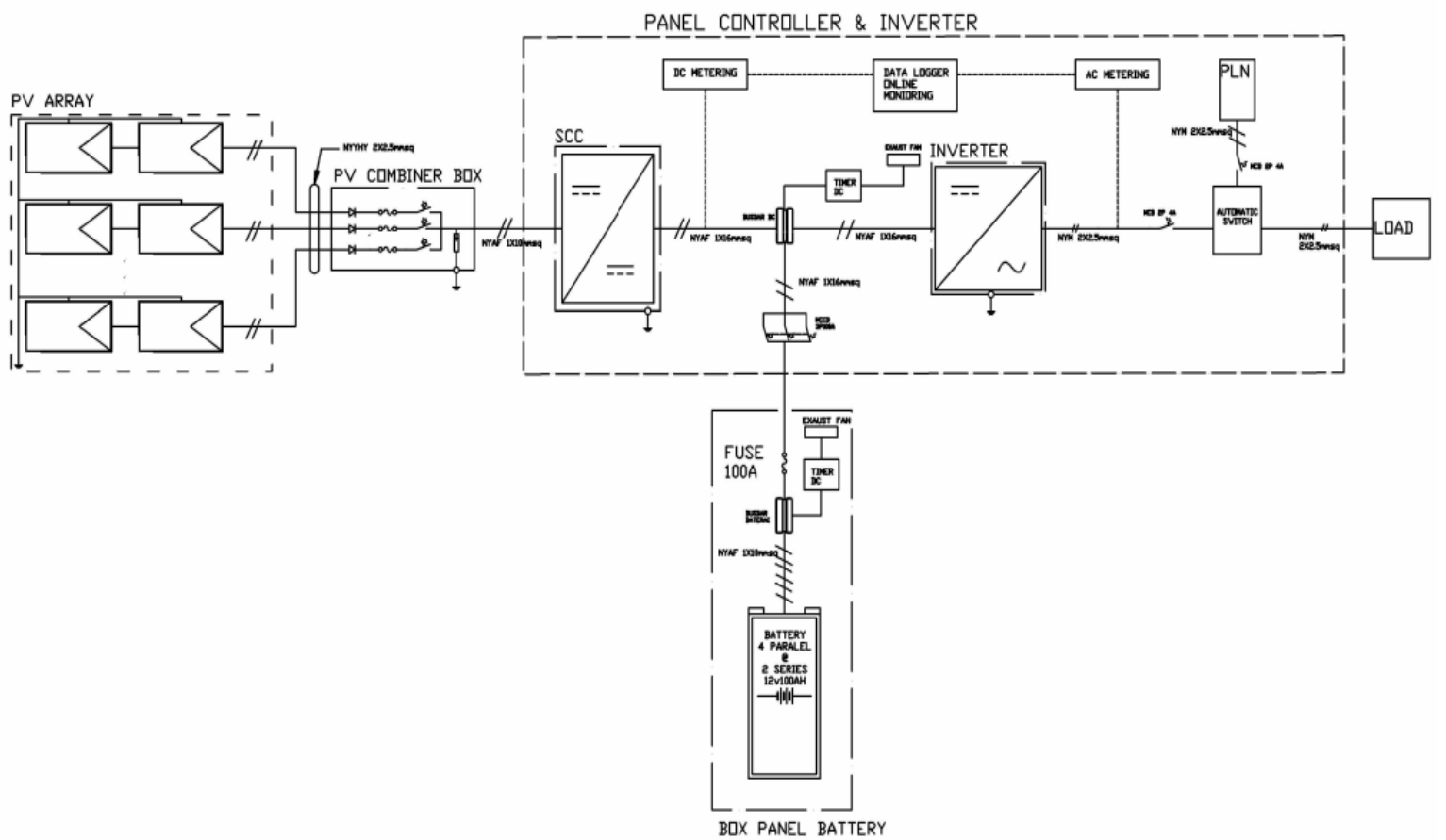

Figure 4. Single line diagram of SHS 
Figure 5 shows the $1 \mathrm{kWp}$ SHS installation on the roof of the Nanizar Zaman Joenoes Building, Airlangga University, Surabaya, Indonesia. Another important thing is the placement of the PV panel array installation and the controller panel considering the topology that is built on top of the building or building. The elevation angle of the PV panel is 10-15 degrees facing the equator. If the location is south of the equator, the PV panel must face north and vice versa. Also, there should be no objects in the direction of the sunlight that has a height more than the PV panel mounting. This can cause shading on the surface of the PV panel array. The minimum height of the mounting feet is $20 \mathrm{~cm}$ from the roof surface. Then the panel distance between the array to the controller panel and the battery panel should not be more than 50 meters. This will cause big losses on the DC side.

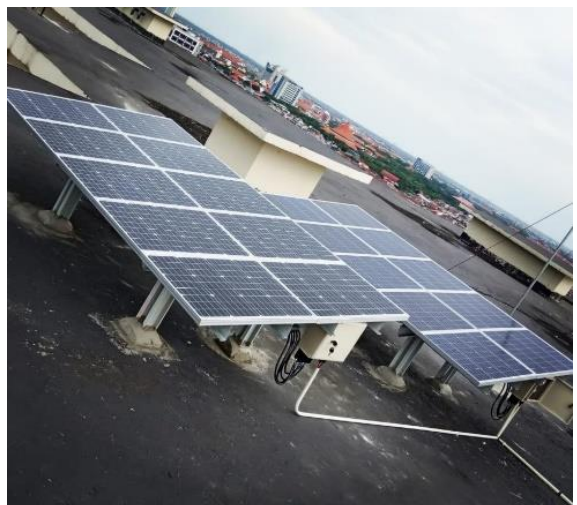

(a)

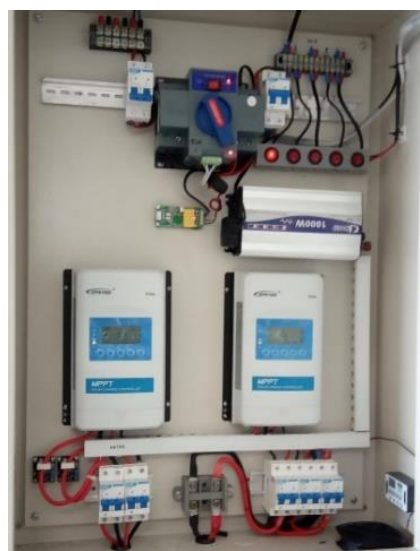

(b)

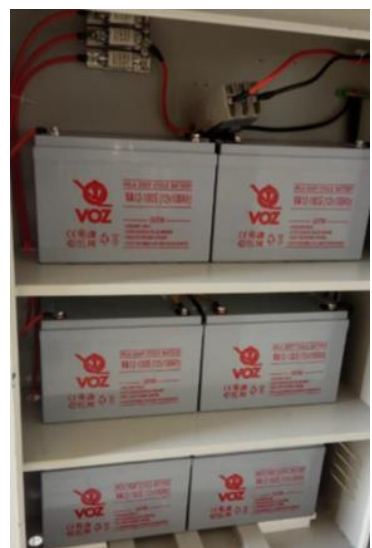

(c)

Figure 5. $1 \mathrm{kWp}$ SHS installation in rooftop; (a) PV panel array, (b) controller panel, and (c) battery bank

\subsection{SHS data analysis}

Data analysis was carried out to determine the performance of the SHS that had been installed with the proposed design. These data are taken from the data logger installed on the SHS controller panel. The file obtained from the data logger has a CSV format. The data logger has been storing SHS data since December 6, 2020. Until the last data collection date, which was February 22, 2021, there were 10002 data. Data sampling by the data logger is carried out in several 5-6 datasets per hour.

Figure 6 shows the energy generated daily and in total. Since this article was written, SHS has only been operating for 3 months. This SHS operates to supply the weather station equipment near the PV array and 10 LED lights. The blue graph shows the daily energy generated during the 3 months that fluctuates. The peak of this generated energy occurs in mid-January. Total energy generated in December 2020 was 16.61 $\mathrm{kWh}$, in January 2021 it was $21.75 \mathrm{kWh}$, in February 2021 it was $16.43 \mathrm{kWh}$.

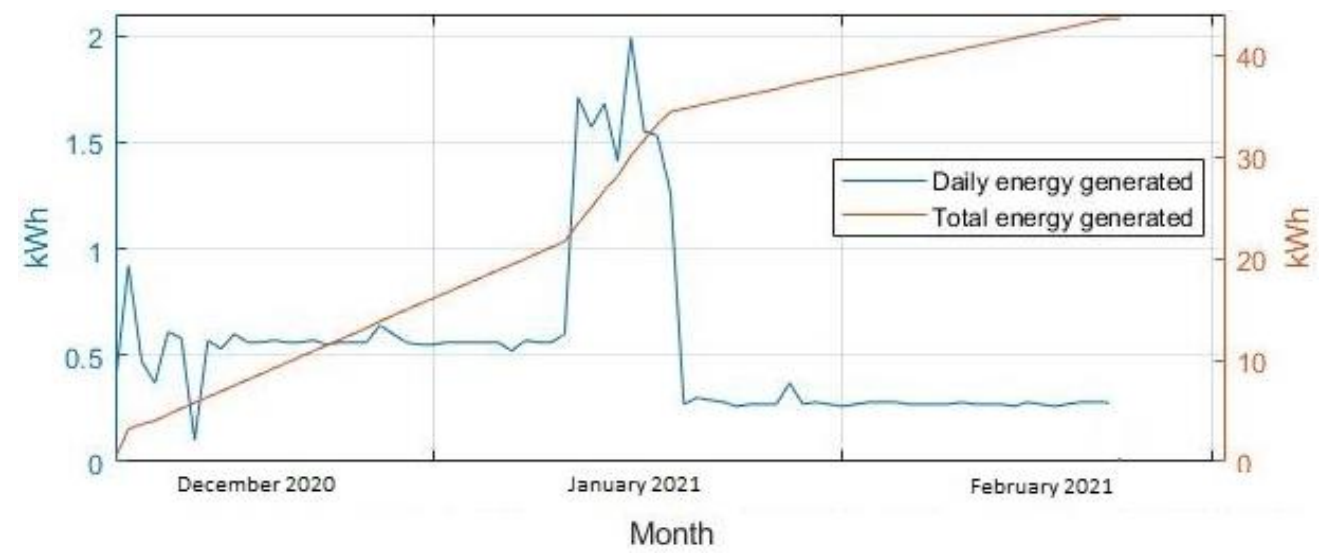

Figure 6. Energy generated in first 3 months of operation 


\section{CONCLUSION}

The design of the SHS has been successfully applied to the rooftop of the Nanizar Zaman Joenoes Building, Airlangga University, Surabaya, Indonesia. The potential for solar energy at that location is an average of $0.37 \mathrm{~W} / \mathrm{m}^{2}$. This design implementation can also be used to design SHS in different locations in Indonesia with specifications that match the required system capacity. The SHS designed to be built has a capacity of $1 \mathrm{kWp}$ with a system specification using a $50 \mathrm{Wp}$ PV panel with a total of 20 units arranged 2 series 10 parallel, 6 battery bank units arranged 2 series 3 parallel, SCC-MPPT $2 \mathrm{~kW}, 200 \mathrm{~W}$ pure sine inverter waves, as well as supporting tools such as data loggers and metering. The SHS that has been built has been operating for 3 months with the total energy generated by $43.55 \mathrm{kWh}$, with an average of $18.2 \mathrm{kWh}$ per month. The limitiation of calculation method presented in this paper is it only can be used to determine the off-grid system with total capacity lower than $30 \mathrm{kWp}$. Also it has less replicable for different load characteristics.

\section{ACKNOWLEDGEMENTS}

We are grateful to the Faculty of Advanced Technology and Multidiscipline (FTMM), also Research and Community Service Institution (LPPM), Universitas Airlangga for providing this internal research grant programme in 2021 .

\section{REFERENCES}

[1] A. Hassan, et al., "A Wirelessly Controlled Robot-based Smart Irrigation System by Exploiting Arduino," J. Robot. Control, vol. 2, no. 1, pp. 29-34, 2020, doi: 10.18196/jrc.2148.

[2] O. Eseosa and N. I. Wariboko, "Proposing Utilization of Photovoltaic (PV) Source into Power Distribution Network Using University of Port Harcourt as a Case Study," J. Robot. Control, vol. 2, no. 4, pp. 274-282, 2021, doi: 10.18196/jrc.2491.

[3] R. Alayi, H. Harasii, and H. Pourderogar, "Modeling and optimization of photovoltaic cells with GA algorithm," $J$. Robot. Control, vol. 2, no. 1, pp. 35-41, 2020, doi: 10.18196/jrc.2149.

[4] A. Z. Abass, D. Pavlyuchenko, and Z. S. Hussain, "Survey about impact voltage instability and transient stability for a power system with an integrated solar combined cycle plant in Iraq by using ETAP," J. Robot. Control, vol. 2, no. 3, pp. 134-139, 2021, doi: 10.18196/jrc.2366.

[5] A. Mezouari, et al., "A New Photovoltaic Energy Sharing System between Homes in Standalone Areas," Int. J. Electr. Comput. Eng. (IJECE), vol. 8, no. 6, pp. 4855-4862, Dec. 2018, doi: 10.11591/ijece.v8i6.pp4855-4862.

[6] T. Turahyo, "A Simple Strategy of Control DC-DC Converter as Power Supply on Household Lights," J. Robot. Control, vol. 2, no. 6, pp. 484-488, 2021, doi: 10.18196/26126.

[7] Y. Apriani, Z. Saleh, R. K. Dillah, and I. M. Sofian, "Analysis of the local energy potential connection with power plants based on archimedes turbine $10 \mathrm{~kW}$, J. Robot. Control, vol. 1, no. 5, pp. 162-166, 2020, doi: 10.18196/jrc.1533.

[8] A. Mehmood, A. Waqas, and H. T. Mahmood, "Economic Viability of Solar Photovoltaic Water Pump for Sustainable Agriculture Growth in Pakistan,” 2015, doi: 10.1016/j.matpr.2015.11.019.

[9] P. Megantoro, F. Danang Wijaya, and E. Firmansyah, "Design of solar water pumping system in urban residential building: (Case study: Yogyakarta, Indonesia)," in 2017 International Conference on Control, Electronics, Renewable Energy and Communications (ICCREC), Sep. 2017, pp. 122-126, doi: 10.1109/ICCEREC.2017.8226696.

[10] B. A. Saputra, E. P. Hidayat, and A. Z. Arfianto, "Internet of Things-Based Steam Pump Motor Protection Due to Voltage Unbalance,” J. Robot. Control, vol. 1, no. 2, pp. 64-69, 2020, doi: 10.18196/jrc.1214.

[11] M. A. Shomad and F. R. Hidayat, "Vertical Blade Fiberglass Composite for Wind Turbine Power Plant Application," J. Robot. Control, vol. 2, no. 3, pp. 148-152, 2021, doi: 10.18196/jrc.2369.

[12] Z. Dzulfikri, N. Nuryanti, and Y. Erdani, "Design and Implementation of Artificial Neural Networks to Predict Wind Directions on Controlling Yaw of Wind Turbine Prototype," J. Robot. Control, vol. 1, no. 1, pp. 20-26, 2020 , doi: 10.18196/jrc.1105.

[13] S. Purwanti, A. Febriani, M. Mardeni, and Y. Irawan, "Temperature Monitoring System for Egg Incubators Using Raspberry Pi3 Based on Internet of Things (IoT)," J. Robot. Control, vol. 2, no. 5, pp. 349-352, 2021, doi: $10.18196 / j \mathrm{jc} .25105$.

[14] I. Prasojo, A. Maseleno, O. Tanane, and N. Shahu, "Design of Automatic Watering System Based on Arduino," J. Robot. Control, vol. 1, no. 2, pp. 55-58, 2020, doi: 10.18196/jrc.1213.

[15] H. Maghfiroh, I. Iftadi, and A. Sujono, "Speed Control of Induction Motor using LQG," J. Robot. Control, vol. 2, no. 6 , pp. 565-570, 2021, doi: 10.18196/26138.

[16] A. A. Mohammed, A. Abdullahi, and A. Ibrahim, "Development of a Prototype Autonomous Electric Vehicle," J. Robot. Control, vol. 2, no. 6, pp. 559-564, 2021, doi: 10.18196/26137.

[17] Zulkiffli Saleh, Y. Apriani, K. Karim, and A. Aldiansyah, "Analysis of Performance of Permanent Magnet Generator Fluks Axial 1 Phasa with Variation Load,” J. Robot. Control, vol. 2, no. 2, pp. 98-102, 2021, doi: $10.18196 /$ jrc. 2260. 
[18] S. Lester, "The Breast," in Robbins and Cotran Pathologic Basis of Disease, 9th ed., V. Kumar, A. Abbas, and J. Aster, Eds. Elsevier, 2015, pp. 1051-1064.

[19] J. Kumar, N. R. Parhyar, M. K. Panjwani, and D. Khan, "Design and performance analysis of PV grid-tied system with energy storage system," Int. J. Electr. Comput. Eng. (IJECE), vol. 11, no. 2, pp. 1077-1085, Apr. 2021, doi: 10.11591/ijece.v11i2.pp1077-1085.

[20] A. A. Adebiyi, I. J. Lazarus, A. K. Saha, and E. E. Ojo, "Performance analysis of grid-tied photovoltaic system under varying weather condition and load," Int. J. Electr. Comput. Eng. (IJECE), vol. 11, no. 1, pp. 94-106, Feb. 2021, doi: 10.11591/ijece.v11i1.pp94-106.

[21] E. Banguero, H. D. Agudelo Arias, A. J. Aristizabal, and D. H. Ospina Baragán, "Renewable microgrid operational results and economic evaluation using RETScreenTM," Int. J. Electr. Comput. Eng. (IJECE), vol. 9, no. 2, pp. 723 731, Apr. 2019, doi: 10.11591/ijece.v9i2.pp723-731.

[22] D. E. Babatunde, O. M. Babatunde, M. Uzoamaka Emezirinwune, I. H. Denwigwe, T. E. Okharedia, and O. J. Omodara, "Feasibility analysis of an off-grid photovoltaic-battery energy system for a farm facility," Int. J. Electr. Comput. Eng. (IJECE), vol. 10, no. 3, pp. 2874-2883, Jun. 2020, doi: 10.11591/ijece.v10i3.pp2874-2883.

[23] A. Grover, A. Khosla, and D. Joshi, "Design and simulation of 20MW photovoltaic power plant using PVSyst," Indones. J. Electr. Eng. Comput. Sci. (IJEECS), vol. 19, no. 1, pp. 58-65, Jul. 2020, doi: 10.11591/ijeecs.v19.i1.pp58-65.

[24] A. O. Njok, F. A. Kamgba, M. K. Panjwani, and F. H. Mangi, "The influence of solar power and solar flux on the efficiency of polycrystalline photovoltaics installed close to a river," Indones. J. Electr. Eng. Comput. Sci. (IJEECS), vol. 17, no. 2, pp. 988-996, Feb. 2020, doi: 10.11591/ijeecs.v17.i2.pp988-996.

[25] N. Kacimi, S. Grouni, A. Idir, and M. Seghir Boucherit, "New improved hybrid MPPT based on neural networkmodel predictive control-kalman filter for photovoltaic system," Indones. J. Electr. Eng. Comput. Sci. (IJEECS), vol. 20, no. 3, pp. 1230-1241, Dec. 2020, doi: 10.11591/ijeecs.v20.i3.pp1230-1241.

[26] F. A. M. Shukor, H. Zainuddin, A. Manja, and F. L. M. Khir, "Sizing verification of a 4kWp retrofitted gridconnected photovoltaic system: a case study in Shah Alam, Malaysia," Indones. J. Electr. Eng. Comput. Sci. (IJEECS), vol. 17, no. 2, pp. 654-661, Feb. 2020, doi: 10.11591/ijeecs.v17.i2.pp654-661.

[27] B. Mohammed, B. Kadri, N. Abdelfatah, and B. Ismail, "Design and modeling of optical reflectors for a PV panel adapted by MPPT control," Indones. J. Electr. Eng. Comput. Sci. (IJEECS), vol. 16, no. 2, pp. 653-660, Nov. 2019, doi: 10.11591/ijeecs.v16.i2.pp653-660.

[28] Z. A. Kamaruzzaman, A. Mohamed, and R. Mohamed, "Optimal placement of grid-connected photovoltaic generators in a power system for voltage stability enhancement," Indones. J. Electr. Eng. Comput. Sci. (IJEECS), vol. 13, no. 1, pp. 339-346, Jan. 2019, doi: 10.11591/ijeecs.v13.i1.pp339-346.

[29] S. Jabr and A. A. Obed, "Photovoltaic flyback micro-inverter with power decoupling technique," Indones. J. Electr. Eng. Comput. Sci. (IJEECS), vol. 15, no. 1, pp. 9-19, Jul. 2019, doi: 10.11591/ijeecs.v15.i1.pp9-19.

[30] R. A. Diantari and I. Pujotomo, "Calculation of electrical energy with solar power plant design," in 2016 International Seminar on Intelligent Technology and Its Applications (ISITIA), Jul. 2016, pp. 443-446, doi: 10.1109/ISITIA.2016.7828701.

[31] C. Khin, P. Buasri, R. Chatthawom, and A. Siritaratiwat, "Estimation of Solar Radiation and Optimal Tilt Angles of Solar Photovoltaic for Khon Kaen University," in 2018 International Electrical Engineering Congress (iEECON), Mar. 2018, pp. 1-4, doi: 10.1109/IEECON.2018.8712118.

[32] M. A. Bukvina, M. A. Falynsky, R. A. Eshenko, and M. A. Popov, "Development of Software for Calculating the Level of Insolation at a Point with Specified Coordinates in Order to Optimize the Construction Site of Solar Power Plants," in 2020 International Multi-Conference on Industrial Engineering and Modern Technologies (FarEastCon), Oct. 2020, pp. 1-5, doi: 10.1109/FarEastCon50210.2020.9271450.

[33] G. L. Morrison and Sudjito, "Solar radiation data for indonesia," Sol. Energy, vol. 49, no. 1, pp. 65-76, Jul. 1992, doi: 10.1016/0038-092X(92)90128-W.

[34] W. Ananda, "External quantum efficiency measurement of solar cell," in 2017 15th International Conference on Quality in Research (QiR) : International Symposium on Electrical and Computer Engineering, Jul. 2017, pp. 450456, doi: 10.1109/QIR.2017.8168528.

[35] P. Megantoro, Y. D. Nugroho, F. Anggara, A. Pakha, and B. A. Pramudita, "The Implementation of Genetic Algorithm to MPPT Technique in a DC/DC Buck Converter under Partial Shading Condition," in 2018 3rd International Conference on Information Technology, Information System and Electrical Engineering (ICITISEE), Nov. 2018, pp. 308-312, doi: 10.1109/ICITISEE.2018.8721005.

[36] N. M. L. Tan, A. K. Ramasamy, V. K. Ramachandaramurthy, M. Marsadek, M. R. Othman, and I. Ariffin, "Utilityscale photovoltaic generators: a review on trends, grid code requirements and challenges," Indones. J. Electr. Eng. Comput. Sci. (IJEECS), vol. 18, no. 2, pp. 573-585, May 2020, doi: 10.11591/ijeecs.v18.i2.pp573-585.

[37] F. Zohra Kessaissia, A. Zegaoui, R. Taleb, C. Fares, and M. Aillerie, "Design of experiments approach for modeling the electrical response of a photovoltaic module," Indones. J. Electr. Eng. Comput. Sci. (IJEECS), vol. 20, no. 3, pp. 1140-1147, Dec. 2020, doi: 10.11591/ijeecs.v20.i3.pp1140-1147.

[38] H. B. Chi, M. F. N. Tajuddin, N. H. Ghazali, A. Azmi, and M. U. Maaz, "Internet of things (IoT) based I-V curve tracer for photovoltaic monitoring systems," Indones. J. Electr. Eng. Comput. Sci. (IJEECS), vol. 13, no. 3, pp. 1022-1030, Mar. 2019, doi: 10.11591/ijeecs.v13.i3.pp1022-1030. 


\section{BIOGRAPHIES OF AUTHORS}
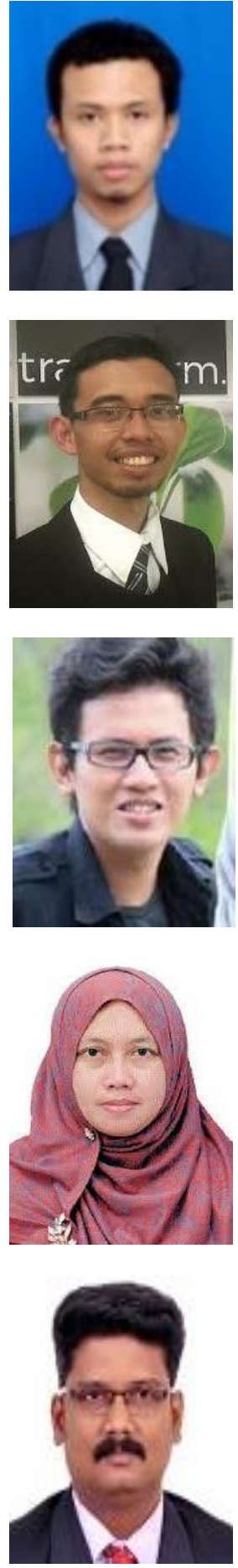

Prisma Megantoro is a lecturer in Electrical Engineering, School of Advanced Technology, and Multidiscipline, Universitas Airlangga since 2020. He received a bachelor's degree and master's degree from Universitas Gadjah Mada, Yogyakarta, Indonesia in 2014 and 2018. His current research is focused on solar photovoltaic technology, embedded system, and the internet of things.

Pinto Anugrah is a lecturer at Department of Electrical Engineering, Faculty of Engineering, Universitas Andalas, Padang, Indonesia. He obtained his bachelor's and master's degree from Universitas Gadjah Mada, Yogyakarta, Indonesia in 2014 and 2016. His research interest includes renewable energy system and planning, solar pv system, smart grid system, and energy for sustainable development.

Yusrizal Afif was born in Surabaya, East Java, Indonesia in 1992. He received Bachelor and Engineering degree in Electrical Engineering from Institut Teknologi Sepuluh Nopember, Surabaya, Indonesia, in 2015. From 2015 to 2017 he worked as project engineer at Krakatau Daya Listrik Co., Indonesia. He received Master Engineering degree in Electrical Engineering from Institut Teknologi Sepuluh Nopember in 2019. He was joined Airlangga University in 2020 as lecturer. His research concentrates mainly on high voltage technology, apparatus characteristics, discharge phenomena and renewable energy.

Lilik J. Awalin was born in East Java, Indonesia, in 1977. She received the B.Eng. degree in electrical engineering in 1999 from the University of Widya Gama, M.Eng. degree in 2004 from the Institut Teknologi Sepuluh Nopember, Indonesia and Ph.D. degree in 2014 from University of Malaya. she was a Senior Lecturer in International College of University Kuala Lumpur, Malaysia from 2015 to 2020. Currently, she is head of section in Airlangga University, Indonesia.

P. Vigneshwaran has obtained his Doctoral Degree in Anna University Chennai during 2016 and Master of Engineering under Anna University Chennai during June 2005. He is having 18.4 years of experience and specialization in Cybersecurity. Presently, He is working as Associate Professor in SRM Institute of Science and Technology, Chennai. His area of interest includes Security, Routing, and Intelligent Data Analysis. 